\title{
Aphyllophorales (Basidiomycetes) of Tiksi, Republic of Sakha (Yakutia), Northeast Siberia
}

\author{
HEIKKI KOTIRANTA and VICTOR A. MUKHIN
}

\begin{abstract}
KOTIRANTA, H. \& MUKHIN, V.A. 2000: Aphyllophorales (Basidiomycetes) of Tiksi, Republic of Sakha (Yakutia), Northeast Siberia - Karstenia 40: 65-69. Helsinki. ISSN 04543-3402.
\end{abstract}

A total of 42 species of wood-inhabiting fungi (mostly Aphyllophorales) were collected in the Republic of Sakha (Yakutia) in the vicinity of the town of Tiksi, which is situated in treeless tundra. All species grew on timber. The most common species proved to be Dacryobolus sudans (Alb. \& Schwein. : Fr.) Fr., Hyphoderma praetermissum (P. Karst.) J. Erikss. \& Å. Strid, H. setigerum (Fr.) Donk, Peniophora incarnata (Pers. : Fr.) P. Karst., Stereum sanguinolentum (Alb. \& Schwein. : Fr.) Fr. and Trametes ochracea (Pers.) Gilb. \& Ryvarden. Athelia pyriformis (M.P. Christ.) Jülich, Subulicium lautum (H.S. Jacks.) Hjortstam \& Ryvarden and Syzygospora mycophaga (M.P. Christ.) Hauerslev are reported from Russia for the first time and some microscopical details of them are given. The dispersal ability and the probable dispersal routes of the species are briefly discussed.

Key words: Aphyllophorales, arctic, timber, Yakutia

Heikki Kotiranta, Finnish Environment Institute, Nature and Land use Division, P.O. Box 140, FIN-00251, Helsinki, Finland.E-mail: heikki.kotiranta@vyh.fi

Victor A. Mukhin, Russian Academy of Sciences, Ural Division, Institute of Plant and Animal Ecology, 8 Marta 202, RUS-620219 Ekaterinburg, Russia. E-mail: victor.mukhin@usu.ru

\section{Introduction}

The authors and Ms. Evghenya Romanova collected fungi in the town of Tiksi and its vicinity (Republic of Sakha, Bulunskiy Ulus). Tiksi $\left(71^{\circ} 38^{\prime} \mathrm{N}, 128^{\circ} 52^{\prime} \mathrm{E}\right)$ is situated on tundra, permafrost area, on the eastern side of the Buor Khaya bay, south east of the delta of the river Lena. According to geomorphological division, this is a part of the Tiksi coastline lowland of the Verkhoyansk Range. The relief includes sloping hills 60-100 $\mathrm{m}$ above sea level.

The arctic shore of Yakutia is an area of excessive humidity (Anonymous 1965), despite the annual precipitation being only about 200-250 $\mathrm{mm}$. Half of this falls in summer (June, July, August). The mean temperature in January is $32^{\circ}-$ $36^{\circ} \mathrm{C}$ below zero, in June-July $+4^{\circ}-+8^{\circ} \mathrm{C}$, the area is snow-covered (average layer of snow 20 cm) 240-280 days a year, and the vegetation period lasts 60-90 days (Anonymous 1986).

The northernmost isolated, open larch stand (Larix gmelinii) (Rupr.) Rupr. lies close to the mouth of the river Lena (Tit-Ary, $72^{\circ} \mathrm{N}$ ) about 80 $\mathrm{km}$ north west of Tiksi and the northern timberline of larch roughly $80 \mathrm{~km}$ south west of Tiksi, along the river Lena. The northern timberline of Picea abies ssp. obovata (Ledeb.) Domin lies ca. 170-180 km south, and of Betula pubescens Ehrh., B. pendula Roth., Populus tremula L. and Pinus sylvestris L. further still, $400 \mathrm{~km}$ south of Tiksi (Sokolov et al. 1977).

The fungi of The Republic of Sakha have been studied earlier by Benois (1926), Karpova-Benois and Benois (1972), Nikadimova (1964), Parmasto $(1975,1976,1977)$, Benois and Karpova-Benois 
(1973), Larsen and Parmasto (1975), Petrenko (1978), Mikhaleva (1993) and Karis and Elliku (1997). These publications mostly deal with polypores, tomentelloid fungi or microfungi, and fairly little is known of the Corticiaceae. Moreover, they are focused on polypores, which grow in forests, and no records derive from the treeless tundra.

Studies which deal with Aphyllophorales in arctic areas elsewhere are also relatively few. Knudsen et al. (1993) list 133 wood-decaying species from Greenland. The investigated areas are much more southerly located (about $60^{\circ}-$ $61^{\circ} \mathrm{N}$ ) and the time spent in the area was almost one month. Unfortunately the authors mention only one species collected from timber (Hyphoderma cryptogallimon B. de Vries) and no comparisons between these two areas can be made. Kotiranta and Penzina (1998) found only three Corticiaceae species (Dendrothele amygdalispora Hjortstam, Peniophora laurentii Lundell and Phlebiella pseudotsugae (Burt) K.H. Larsson \& Hjortstam) from Cape Nyarusalye on the coast of the Kara Sea in the northern part of the Yamal Peninsula in West Siberia (see Goldberg \& Romanova 1996, p. 14). The studies from Svalbard (Dobbs 1942, Kobayasi \& al. 1968, Ohenoja 1971, Gulden \& Torkelsen 1996) mostly deal with fungi other than Aphyllophorales, even if Gulden and Torkelsen (1996) list two polypore species (Antrodia serialis, Gloeophyllum sepiarium) and eight Corticiaceae species. Kobayasi et al. $(1967,1969)$ list fewer than ten Aphyllophoroid taxa from arctic Alaska.

\footnotetext{
Material and methods

The collecting took place August 10-11, 1999, in strong wind and rain. All the material is collected from structural wood, timber, boards, driftwood, etc. The timber mostly consists of Larix gmelinii and Pinus sylvestris, less often of Picea abies ssp. obovata, Betula spp. and Populus tremula (mostly driftwood). Thus, the overwhelming majority of species were collected from coniferous wood. The specimens were studied microscopically in Cotton Blue (abbreviated CB), Melzer's reagent (abbr. IKI) and $5 \% \mathrm{KOH}$. In the text the following abbreviations are used: $\mathrm{L}=$ mean spore length (arithmetical mean of the measured spores), $\mathrm{W}=$ mean spore width, $\mathrm{Q}=$ range of the variation in $\mathrm{L} / \mathrm{W}$ ratio, $\mathrm{Q}^{*}=$ quotient of the mean spore length and mean spore width (L/W ratio). The measurements contain 30 spores per specimen. The material is preserved either in the herbarium of Helsinki $(\mathrm{H})$ or Ekaterinburg (IEE). The nomenclature of polypores follows Niemelä (1999) and of Corticiaceae Hansen and Knudsen (1997).
}

\section{Results}

List of species

Amylocorticium subsulphureum (P. Karst.) Pouzar, (conifer 4)

Amyloporia xantha (Fr.: Fr.) Bondartsev \&

Singer, (conifer 2)

Antrodia serialis (Fr.) Donk, (conifer)

Antrodia sinuosa (Fr.) P. Karsten, (conifer)

Athelia epiphylla Pers. : Fr., (conifer 3)

Athelia pyriformis (M.P. Christ.) Jülich, (conifer)

Ceraceomyces serpens (Tode : Fr.) Ginns,

(conifer)

Chondrostereum purpureum (Pers : Fr.) Pouzar, (Populus)

Crucibulum laeve (Huds.) Kambly (conifer 5)

Cylindrobasidium laeve (Pers. : Fr.) Chamuris, (conifer 2, Populus 3)

Dacryobolus sudans (Alb. \& Schwein. : Fr.) Fr., (conifer 6)

Exidia saccharina (Alb. \& Schwein. : Fr.) Fr., (Larix 5)

Flammulina velutipes (Curt. : Fr.) Sing.,

(Populus)

Hymenochaete "laricis" ined. (Larix)

Hyphoderma praetermissum (P. Karst.) J. Erikss. $\& \AA \AA$. Strid, (conifer 10)

Hyphoderma setigerum (Fr.) Donk, (conifer 10)

Hyphodontia alutacea (Fr.) J. Erikss., (conifer 2)

Hyphodontia cf. nespori (Bres.) J. Erikss. \& Hjortstam, (conifer)

Hyphodontia sambuci (Pers. : Fr.) J. Erikss., (conifer 2)

Hyphodontia subalutacea (P. Karst.) J. Erikss., (conifer)

Hypochniciellum molle (Fr.) Hjortstam, (conifer)

Laurilia sulcata (Burt) Pouzar, (Larix)

Leptoporus mollis (Pers. : Fr.) Quél., (Picea)

Merismodes anomalus (Pers. : Fr.) Sing.,

(Populus)

Peniophora incarnata (Pers. : Fr.) P. Karst., (Betula 6)

Peniophora pithya (Pers.) J. Erikss., (conifer)

Phlebiella sulphurea (Pers. : Fr.) Ginns \& Lefebre, (conifer)

Phlebiopsis gigantea (Fr. : Fr.) Jülich, (conifer 5)

Postia cf. caesia (Schrad. : Fr.) P. Karst., (conifer)

Schizophyllum commune Fr.: Fr., (Betula)

Sistotrema binucleosporum Hallenberg,

(conifer)

Sistotrema brinkmannii (Bres.) J. Erikss., (conifer 3) 
Stereum hirsutum (Willd. : Fr.) Gray, (Betula 2.)

Stereum sanguinolentum (Alb. \& Schwein. : Fr.) Fr., (Larix 5, Pinus 3)

Subulicium lautum (H.S. Jacks.) Hjortstam \& Ryvarden, (conifer 2)

Subulicystidium longisporum (Pat.) Parmasto, (conifer)

Syzygospora mycophaga (M.P. Christ.)

Hauerslev, (Hypochniciellum molle/conifer)

Thanatephorus cucumeris (Frank) Donk, (conifer)

Trametes ochracea (Pers.) Gilb. \& Ryvarden, (Populus 7)

Tremella encephala Pers. : Fr., (Stereum

sanguinolentum/Larix)

Trichaptum fuscoviolaceum (Ehrenb. : Fr.)

Ryvarden, (conifer 2)

The most common species were Dacryobolus sudans, Hyphoderma praetermissum, H. setigerum, Peniophora incarnata, S. sanguinolentum and Trametes ochracea. The ratio Corticiaceae/polypores in this material is $4: 1$. All species, except Laurilia sulcata, form annual fruit bodies (Stereum hirsutum, S. sanguinolentum, Antrodia serialis sometimes biennial). The overwhelming majority of all the species are white-rot fungi. Among the polypores the situation is quite the reverse: five of the seven species (71\%) are brown-rot fungi (Amyloporia xantha, Antrodia serialis, A. sinuosa, Leptoporus mollis, Postia cf. caesia). Besides these polypores only $D$. sudans and $H$. molle cause brown rot.

\section{Rare species}

Athelia pyriformis (M.P. Christ.) Jülich (Fig. 1) New to Russia. Fruit body resupinate, thin, whitish, finely porulose under the lens $(\times 10)$, not

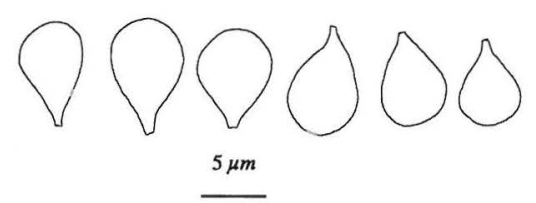

Fig. 1. Athelia pyriformis (M.P. Christ.) Jülich. Spores. (Kotiranta 15970 \& Romanova).

athelioid. Hyphal system monomitic, all hyphae simple septate. Basal hyphae sparingly septate, up to $7 \mu \mathrm{m}$ wide with thickened walls. Subhymenial hyphae $4 \mu \mathrm{m}$ wide, thin-walled, very faintly $\mathrm{CB}+, \mathrm{IKI}-$. Cystidia none. Basidia clavate, basally simple septate, stalked, (15-) 18-23 × (5.5-) $6.5-7.5 \mu \mathrm{m}$, with four, up to $6 \mu \mathrm{m}$ long sterigmata. Spores pyriform or lacrymoid, (5.2-) 5.9-7.0 (7.4) $\times(4.0-) 4.7-5.6(-6.2) \mu \mathrm{m}, \mathrm{L}=6.5 \mu \mathrm{m}, \mathrm{W}=4.9$ $\mu \mathrm{m}, \mathrm{Q}=1.1-1.4, \mathrm{Q}^{*}=1.3$ (Kotiranta $15969 \&$ Romanova) with a prominent apicular region, thin-walled, CB-(contents blue), IKI-.

Subulicium lautum (H.C. Jacks.) Hjortstam \& Ryvarden (Fig. 2)

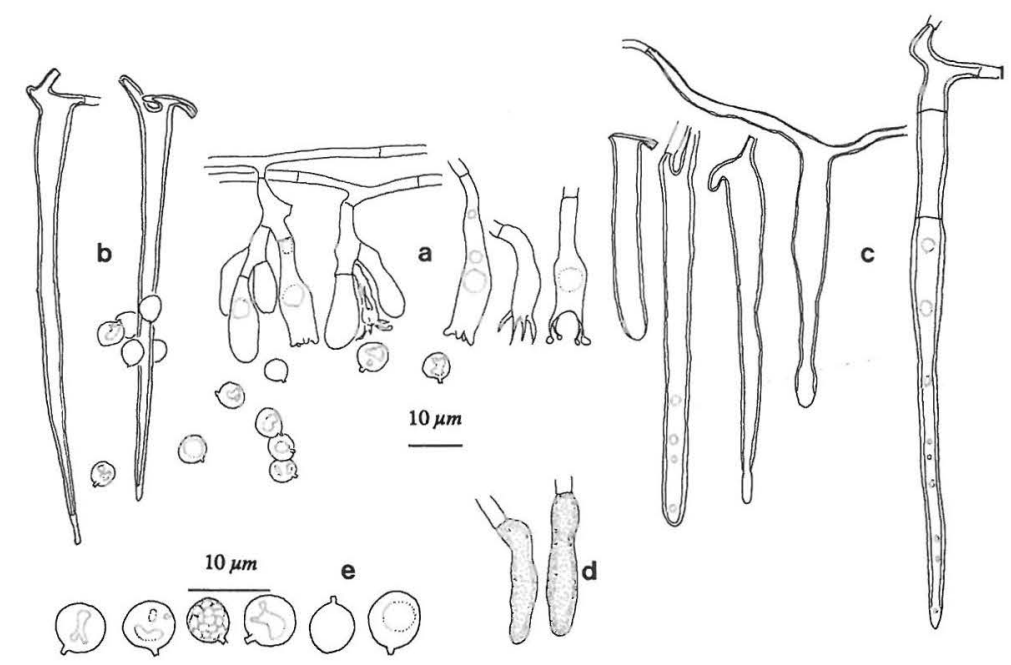

Fig. 2. Subulicium lautum (H.C. Jacks.) Hjortstam \& Ryvarden. - a) basidia of different stages of development, b), c) cystidia, d) gloeocystidia, e) spores. (Kotiranta 15970 \& Romanova a, b, e, Kotiranta 15972 \& Romanova c, d). 
New to Russia. Fruit body resupinate, thin or very thin, pale creamy ochraceous, finely reticulate porose under the lens $(\times 25)$, pilose due to the abundant protruding cystidia. Hyphal system monomitic, all hyphae simple septate. Basal hyphae sparingly branched, $2-2.5 \mu \mathrm{m}$ wide, thinwalled, subhymenial hyphae up to $4 \mu \mathrm{m}$ in diam. Cystidia abundant, two or three rooted, sharp pointed or with a mucronate tip, seldom with one or two adventitious septa, (95-) 100-120 × 7-9 $\mu \mathrm{m}$, with up to $1 \mu \mathrm{m}$ thick walls (also the tip is mostly thick-walled), cyanophilous, IKI-. Gloeocystidia few, $30-37(-43) \times 5 \mu \mathrm{m}$. Basidia clavate, often clearly stalked, (22-) 25-30 × (6-) 7.5-8.5 $\mu \mathrm{m}$, with four, up to $8 \mu \mathrm{m}$ long sterigmata. Spores subglobose or globose, 5.8-7.0 (-8.2) × 4.6-6.3 $(-8.0) \mu \mathrm{m}, \mathrm{L}=6.3 \mu \mathrm{m}, \mathrm{W}=5.7 \mu \mathrm{m}, \mathrm{Q}=1.0-1.4, \mathrm{Q}^{*}$ $=1.1$ (Kotiranta $15970 \&$ Romanova), 5.1-6.4 $(-6.6) \times 4.5-5.5(-5.9) \mu \mathrm{m}, \mathrm{L}=5.7, \mathrm{~W}=5.1, \mathrm{Q}=$ 1.0-1.3, Q* $=1.1$ (Kotiranta 15972 \& Romanova), thin- to slightly thick-walled, $\mathrm{CB}$ - (or very faintly $\mathrm{CB}+$ ), IKI-.

Subulicium lautum is considered to be an oldgrowth forest species (Eriksson \& al. 1984) and the treeless tundra would not appear to fit such a description (see also Losi 1999, p. 85). However, the microclimatic conditions during the growth period in old-growth forests are constantly humid, thus resembling the conditions here in the tundra.

\section{Syzygospora mycophaga (M.P. Christ.) \\ Hauerslev}

New to Russia. The fruit body observable under the lens as pinkish, velutinous appearance on hosts surface. Hyphal system monomitic, all hyphae clamped, 1.5-2 $\mu \mathrm{m}$ wide, very thin-walled. Haustoria 0.7-0.8 $\mu \mathrm{m}$ wide, very thin-walled. Cystidia none, but bulbous or clavate conidiophores abundant. Conidia ellipsoid, (5.1-) 5.5$6.6(-7.1) \times 2.6-3.5(-4.0) \mu \mathrm{m}, \mathrm{L}=6.2 \mu \mathrm{m}, \mathrm{W}=3.1$ $\mu \mathrm{m}, \mathrm{Q}=1.6-2.6, \mathrm{Q}^{*}=2.0$. Basidia tubular, basally clamped, often basally widened, (23-) 29-43 $(-50) \times(4-) 5-8 \mu \mathrm{m}$, with four, up to $6.5 \mu \mathrm{m}$ long sterigmata. Spores broadly ellipsoid or almost subglobose, (5.5-) 5.7-7.0 × 4.3-5.1 (-5.5) $\mu \mathrm{m}$, $\mathrm{L}=6.3 \mu \mathrm{m}, \mathrm{W}=4.8 \mu \mathrm{m}, \mathrm{Q}=1.2-1.5, \mathrm{Q}^{*}=1.3$ (Kotiranta 15995b \& Romanova) with thickened walls, CB-, IKI-, germinating by a small roundish cell. These sprout cells arise either from the apical or from the basal end; in this specimen the ratio is $50: 50$.
Kotiranta and Saarenoksa (2000) illustrates and describes Finnish specimens of $S$. mycophaga. The Russian specimen is very similar to the Finnish ones, which grew together with $H$. molle.

\section{Discussion}

The dispersal ability of the observed species is undoubtedly good. Moreover, they can colonise small pieces of structural wood. This is also true in more southern areas and the phenomenon could be expected to occur also here. Naturally, the climate does not restrict their distribution in the north, but rather the scarcity of suitable substrate in favourable sites; there were plenty of "good looking" pieces of wood which, however, were without fruit bodies.

The dispersal of spores via air from the closest natural sources is one route, but most probably not the only one. The second route is (very probably) that the species invade the treeless areas step by step. Along the shores of the river Lena there are plenty of trunks which have escaped during the float of logs down the river. The stream also constantly changes its bed, and huge numbers of trunks fall annually into the water. All these logs and trunks offer footsteps for the species, and they "jump" step by step from one log to another on their way to the north. The third route is at least as likely as the two first ones: the barked logs contain spores already when they are cut in the more southern areas, and the spores survive the harsh floating conditions and are able to germinate when the logs are thrown by wind or man to the shore. Some trunks may also have been infested already by mycelia during storage, before the floating. This is an apparent pathway for aggressive decayers of newly fallen trees, like Amyloporia xantha, Antrodia serialis, A. sinuosa, Schizophyllum commune, Stereum sanguinolentum, Trametes ochracea and Trichaptum fuscoviolaceum.

A common feature of almost every species was that the fruit bodies were very small. The exceptions are Amyloporia xantha, Antrodia serialis, A. sinuosa, Laurilia sulcata, Stereum sanguinolentum, Trametes ochracea and Trichaptum fuscoviolaceum - species that also in natural habitats develop more or less extensive fruit bodies.

It would be interesting to study the species composition in areas like Tiksi over a long period 
to clarify the changes in species composition. Our "enlightened guess" is that the common species survive (as they have survived until now) without big changes in abundance. The species with one or two records only, are perhaps species that do not have a reproductive population big enough to remain or get a constant foothold.

Acknowledgements: Financial support to Heikki Kotiranta from the Academy of Finland (project NO. 64750) and Victor A. Mukhin from the Russian Fund for Fundamental Research (NO 98-04-48768; subprogram "Biological diversity") is gratefully acknowledged. Ms. Evghenya Romanova (University of Ekaterinburg) is warmly thanked for her patient help in the field in a somewhat unfriendly environment. The English language was reviewed by Michael Collinson, M.A.; also he is warmly thanked.

\section{References}

Anonymous 1965: Yakutia. - Izdatelstvo Nauka, Moskva. $465 \mathrm{pp}$.

Anonymous 1986: Atlas SSSR 1986. - Glavnoe upravlenie geodezii i kartografii pri Sovete Ministrov SSSR, Moskva. 260 pp.

Benois, K.A. 1926: Kratkii predvaritelnyi obzor mikologicheskikh i fitopatologicheskikh obsledovanii Yakutskogo kray a letom 1925 goda. - Mat. Mikol. Fitopatol. 5: 92-97.

Benois, K.A. \& Karpova-Benois, E.I. 1973: Parazitnye griby Yakutii (Peronosporye, muchnistorosyanye, golovnevye i rzhavchinnye). - Izdatel'stvo Nauka, Sibirskoe Otdelenie, Novosibirsk. 335 pp.

Dobbs, C.G. 1942: Note on the larger fungi of Spitsbergen. - J. Bot. 80: 94-101.

Eriksson, J., Hjortstam, K. \& Ryvarden, L. 1984: The Corticiaceae of North Europe 7. Schizopora to Suillosporium. - Fungiflora, Oslo. Pp. 1281-1449.

Goldberg, I. \& Romanova, E. 1998: The Fifth International Symposium on Arcto-Alpine Mycology, Labytnangi, Russia, August 15-27, 1996. - Arctic Alpine Mycol. 5: 10-14.

Gulden, G. \& Torkelsen, A-E. 1996: Fungi 1. Basidiomycota: Agaricales, Gasteromycetales, Aphyllophorales, Exobasidiales, Dacrymycetales and Tremellales. In: Elvebakk, A. \& Prestrud, P. (eds.), A catalogue of Svalbard plants, fungi, algae and cyanobacteria. Norsk Polarinst. Skrift. 198: 173-198.

Hansen, L. \& Knudsen, H. (eds.) 1997: Nordic macromycetes 3. Heterobasidioid, aphyllophoroid and gasteromycetoid Basidiomycetes. - Nordsvamp, Copenhagen. 445 pp.

Karis, H. \& Elliku, J. 1997: On the powdery mildews (Erysiphaceae) of Yakutia. - Fol. Crypt. Estonica 31: 46-47.
Karpova-Benois, E.I. \& Benois, K.A. 1972: Fungi Basidiales lignum destruentes et parasitici in Republica Autonoma Jacutiae inventi. - Nov. Syst. Plant. Vascul. 9: 139-151.

Knudsen, H., Hallenberg, N. \& Mukhin, V. 1993: A comparison of wood-inhabiting basidiomycetes from three valleys in Greenland. - Bibl. Mycol. 150: 133145.

Kobayasi, Y., Hiratsuka, N., Korf, R.P., Tubaki, K., Aoshima, K., Soneda, M. \& Sugiyama, J. 1967: Mycological studies of the Alaskan arctic. - Ann. Rep. Inst. Ferm. Osaka 3: 1-138.

Kobayasi, Y., Hiratsuka, N., Otani, Y., Tubaki, K., Udagawa, S. \& Soneda, M. 1969: The second report on the mycological flora of the Alaskan arctic. - Bull. Nat. Sci. Mus. Tokyo 12: 311-429.

Kobayasi, Y., Tubaki, K. \& Soneda, M. 1968: Enumeration of the higher fungi, moulds and yeasts of Spitsbergen. - Bull. Nat. Sci. Mus. Tokyo 11: 33-76.

Kotiranta, H. \& Penzina, T. 1998: Notes on the North Ural Aphyllophorales (Basidiomycetes). - Arctic Alpine Mycol. 5: 67-81.

Kotiranta, H. \& Saarenoksa, R. 2000: Corticioid fungi (Aphyllophorales, Basidiomycetes) in Finland - Acta Bot. Fennica 168: 1-55.

Larsen, M.J. \& Parmasto, E. 1975: Studies on Yakutian fungi 1. Introduction. Thelephoraceae s.str. - Eesti NSV Tead. Akad. Toim., Biol. Seer. 24: 217-226.

Losi, C. 1999: Macrofungus flora of the lagoon of Venice and adjacent areas (Italy). Non-gilled Basidiomycetes 2. Corticioid fungi. - Mycotaxon 71: 69-87.

Mikhaleva, L.G. 1993: Preliminary data to the study of wood-destroying Aphylloporaceous fungi of Yakutia. - Mikol. Fitopatol. 27: 16-26.

Niemelä, T. 1999: Suomen kääpien määritysopas. Guide to the polypores of Finland. 12th revised edition. Bot. Bull. Univ. Helsinki 169: 1-138.

Nikadimova, N, F. 1964: Kratkiy obzor bolezney i gribnoy flory drevostoev severnego i srednego Aldana. Lesa Yuzhnoi Yakutii. Pp. 144-147.

Ohenoja, E. 1971: The larger fungi of Svalbard and their ecology. - Rep. Kevo Subarctic Res. Sta. 8: 122-147.

Parmasto, E. 1975: Studies on Yakutian fungi 1. Corticiaceae, Thelephoraceae. - Eesti NSV Tead. Akad. Toim., Biol. Seer. 24: 3-15.

Parmasto, E. 1976: Studies on Yakutian fungi 2. Ganodermataceae, Hymenochaetaceae, Polyporaceae. Eesti NSV Tead. Akad. Toim., Biol. Seer. 26: 15-28.

Parmasto, E. 1977: Studies on Yakutian fungi 3. Polyporaceae, Poriaceae s.l. - Eesti NSV Teaduste Akad. Toim., Biol. Seer. 26:15-28.

Petrenko, I.A. 1978: Makro- i mikromitsety Tsentralnoy Yakutii. - Nauka, Novosibirsk. 133 pp.

Sokolov, S.Y., Svyazeva, O.A. \& Kubli, V.A. 1977: Arealy derevyev i kustarnikov SSSR 1. - Nauka, Leningrad. 164 pp. 